\title{
Lactobacillus capillatus sp. nov., a motile bacterium isolated from stinky tofu brine
}

\author{
Shiou-Huei Chao, ${ }^{1}$ Yasuaki Tomii, ${ }^{2}$ Masae Sasamoto, ${ }^{2}$ Junji Fujimoto, ${ }^{2}$ \\ Ying-Chieh Tsai ${ }^{1}$ and Koichi Watanabe ${ }^{2}$ \\ ${ }^{1}$ Institute of Biochemistry, National Yang-Ming University, 155 Sec. 2, Li-Nong Street, Pei-Tou, \\ Taipei 11221, Taiwan, ROC \\ ${ }^{2}$ Yakult Central Institute for Microbiological Research, 1796 Yaho, Kunitachi, Tokyo 186-8650, \\ Japan
}

Correspondence

Koichi Watanabe

koichi-watanabe@yakult.co.jp

\begin{abstract}
Three Gram-positive, catalase-negative, motile, rod-shaped bacteria were isolated from fermented stinky tofu brine. These strains, designated YIT $11306^{\top}$, YIT 11317 and YIT 11318 , were discriminated from five isolates on the basis of randomly amplified polymorphic DNA profiles. They produced L-lactic acid as the main end product from glucose without gas formation, synthesized dextran from sucrose and hydrolysed aesculin. Ammonia was not produced from arginine. Comparative 16S rRNA gene sequence analysis demonstrated that the novel isolates were members of the genus Lactobacillus. Based on levels of 16S rRNA gene sequence similarity, the three novel strains were related most closely to the type strains of Lactobacillus mali (97.2\%) and Lactobacillus satsumensis (96.8\%). However, levels of DNA-DNA relatedness between the novel isolates and the type strains of $L$. mali and $L$. satsumensis were less than $10 \%$. The phenotypic and genotypic data demonstrate that the three strains represent a single novel species of the genus Lactobacillus, for which the name Lactobacillus capillatus sp. nov. is proposed. The type strain is YIT $11306^{\top}\left(=\mathrm{JCM} 15044^{\top}=\mathrm{BCRC} 17811^{\top}=\mathrm{DSM} 19910^{\top}\right)$.
\end{abstract}

Stinky tofu is a well-known and popular traditional fermented Chinese snack, and its manufacturing process differs from region to region. In Taiwan, stinky tofu is made by immersing tofu into fermented stinky brine, thus permeating the tofu with the odour of the brine. Stinky brine can be made entirely by mixing vegetables or may also include Chinese herbs, shrimp or fish to give a unique and strong odour. All of the raw materials decompose by natural fermentation, and the resulting liquid is the fermented brine used for production of stinky tofu.

During the course of a study of the biodiversity of lactic acid bacteria in stinky tofu brines, three Lactobacillus-like strains, designated YIT $11306^{\mathrm{T}}$, YIT 11317 and YIT 11318, could not be clearly placed within any recognized species of the genus by means of $16 \mathrm{~S}$ rRNA gene sequence similarity. These strains are shown here to represent a single novel species of the genus Lactobacillus.

Abbreviation: RAPD, randomly amplified polymorphic DNA.

The GenBank/EMBL/DDBJ accession numbers for the $16 \mathrm{~S}$ rRNA gene sequences of strains YIT $11306^{\top}$, YIT 11317 and YIT 11318 are AB365976, AB365977 and AB365978, respectively.

Maximum-parsimony and maximum-likelihood phylogenetic trees based on 16S rRNA gene sequences showing the relationship of strains YIT $11306^{\top}$, YIT 11317 and YIT 11318 to closely related Lactobacillus species are available as supplementary material with the online version of this paper.
Samples of fermented stinky brines were obtained in May 2005 from a factory for the manufacture of stinky tofu in Taipei County, Taiwan. Samples were taken aseptically, stored at $4{ }^{\circ} \mathrm{C}$ and analysed within $24 \mathrm{~h}$. Stinky tofu brine samples were inoculated onto de Man-Rogosa-Sharpe (MRS; Difco) agar supplemented with $0.001 \%$ sodium azide and $0.001 \%$ cycloheximide and incubated anaerobically at $30{ }^{\circ} \mathrm{C}$ for 3 days. Cell counts of lactic acid bacteria were $4.2 \times 10^{3}-1.2 \times 10^{6}$ c.f.u. $\mathrm{ml}^{-1}$, and 168 isolates were collected for further analysis. The selected isolates were stored at $-80{ }^{\circ} \mathrm{C}$ in nutrient broth (BD; Difco) containing $10 \%(\mathrm{v} / \mathrm{v})$ DMSO. The present study describes the characterization of three strains (YIT $11306{ }^{\mathrm{T}}$, YIT 11317 and YIT 11318) from the 168 isolates. Lactobacillus agilis YIT $0253^{\mathrm{T}}$, Lactobacillus mali YIT $0449^{\mathrm{T}}$, Lactobacillus salivarius subsp. salivarius YIT $0104^{\mathrm{T}}$ and Lactobacillus satsumensis YIT $11287^{\mathrm{T}}$ were obtained from the culture collection of the Yakult Central Institute (YIT; Tokyo, Japan) and were used as reference strains. The test strains were cultivated and maintained in MRS broth $(\mathrm{pH} 7.0)$ at $30{ }^{\circ} \mathrm{C}$ for 1 or 2 days, unless indicated otherwise.

Chromosomal DNA used as template for randomly amplified polymorphic DNA (RAPD) typing and $16 \mathrm{~S}$ rRNA gene sequence amplification was prepared from the isolates according to the method of Zhu et al. (1993). Five isolates [ST-A9a ${ }^{\mathrm{T}}\left(=\right.$ YIT $\left.11306^{\mathrm{T}}\right)$, ST-A31a $(=$ YIT 11317), 
ST-A32a, ST-A33a (=YIT 11318) and ST-A39a] were initially screened by using RAPD fingerprinting as described by Akopyanz et al. (1992), with the following modification. Briefly, PCR was performed in $20 \mu \mathrm{l}$ of a mixture containing $10 \mathrm{mM}$ Tris/ $\mathrm{HCl}(\mathrm{pH} 8.3), 50 \mathrm{mM}$ $\mathrm{KCl}, 2.5 \mathrm{mM} \mathrm{MgCl}_{2}, 1.6 \mu \mathrm{M}$ primer, $200 \mu \mathrm{M}$ of each dNTP, $1.5 \mathrm{U}$ Taq polymerase (Takara Bio Inc.) and $10 \mu \mathrm{g}$ template DNA. Primers A (5'-CCGCAGCCAA- $\left.3^{\prime}\right), \mathrm{B}\left(5^{\prime}-\right.$ AACGCGCAAC-3') and C (5'-GCGGAAATAG-3') were used in the present study. The PCR cycling programme consisted of one cycle of $94{ }^{\circ} \mathrm{C}$ for $2 \mathrm{~min}$, six cycles of $94{ }^{\circ} \mathrm{C}$ for $30 \mathrm{~s}, 36{ }^{\circ} \mathrm{C}$ for $1 \mathrm{~min}$ and $72{ }^{\circ} \mathrm{C}$ for $90 \mathrm{~s}, 30$ cycles of $94{ }^{\circ} \mathrm{C}$ for $20 \mathrm{~s}, 36{ }^{\circ} \mathrm{C}$ for $30 \mathrm{~s}$ and $72{ }^{\circ} \mathrm{C}$ for $90 \mathrm{~s}$, and finally one cycle of $72{ }^{\circ} \mathrm{C}$ for $3 \mathrm{~min}$. Isolates ST-A31a and ST-A32a had identical RAPD profiles, as did isolates ST-A33a and ST-A39a (Fig. 1). Analysis of these profiles indicated that the five isolates could be discriminated into three strains, namely YIT $11306^{\mathrm{T}}$, YIT 11317 and YIT 11318.

Conditions for PCR amplification of the almost-complete $16 \mathrm{~S}$ rRNA gene and subsequent DNA sequencing were as described by Miyake et al. (1998). Sequence assembly was performed by using the programs AUTOASSEMBLER version 2.1 (Applied Biosystems) and GENETYX-MAC version 13.0.1 (Software Development). The closest known relatives of the novel strains were determined according to the program FASTA. The 16S rRNA gene sequences (about $1460 \mathrm{bp}$ ) of strains YIT $11306^{\mathrm{T}}$, YIT 11317 and YIT 11318 and of those of their closest relatives retrieved from the DDBJ/GenBank/ EMBL databases were aligned by using the CLUSTAL_X program (version 1.82) (Thompson et al., 1997). A phylogenetic tree was constructed with the neighbourjoining method (Saitou \& Nei, 1987) by using the CLUSTAL_X program. The statistical reliability of the tree was evaluated by bootstrap analysis of 1000 replicates

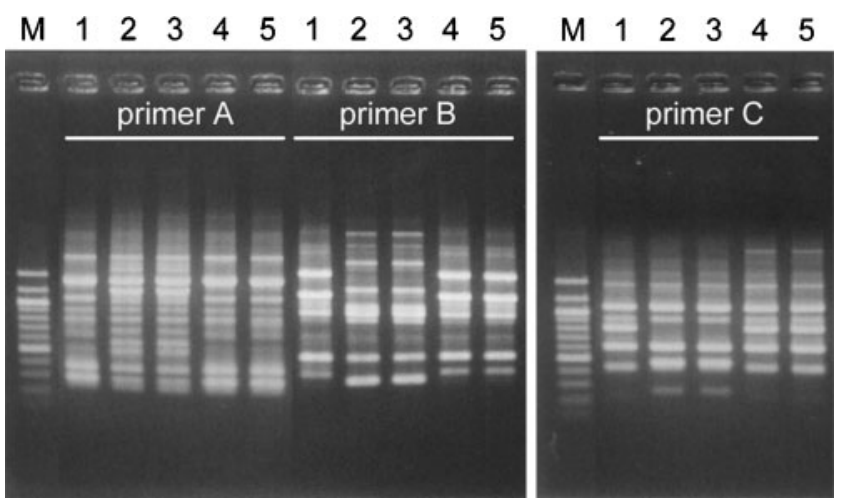

Fig. 1. Genetic relatedness among five novel Lactobacillus isolates by using RAPD-PCR analysis. Three primers with random sequences ( $A, B$ and $C$ ) were used. Lane $M, 100-b p$ ladder DNA size marker (Seegene); lanes 1-5, isolates ST-A9a ${ }^{\top}\left(Y_{1 T} 11306^{\top}\right)$, ST-A31a (YIT 11317), ST-A32a and ST-A33a (YIT 11318), and ST-A39a, respectively.
(Felsenstein, 1985) and the tree topology was also confirmed with the maximum-parsimony (Fitch, 1971) and maximum-likelihood (Cavalli-Sforza \& Edwards, 1967) methods, by using PHYLIP version 3.67 (Felsenstein, 2007). Levels of $16 \mathrm{~S}$ rRNA gene sequence similarity between strain YIT $11306^{\mathrm{T}}$ and strains YIT 11317 and YIT 11318 were 99.6 and $99.9 \%$, respectively. Levels of similarity between strain YIT $11306^{\mathrm{T}}$ and its nearest neighbours, L. mali YIT $0449^{\mathrm{T}}$ and L. satsumensis YIT $11287^{\mathrm{T}}$, were 97.2 and $96.8 \%$, respectively. Based on a neighbour-joining analysis, the novel strains did not belong to any existing phylogenetic groups and formed a distinct subcluster within the $L$. mali cluster, comprising $L$. mali and L. satsumensis (Fig. 2). Similar tree topologies were obtained by using the maximum-parsimony and maximum-likelihood methods (see Supplementary Figs S1 and S2, available in IJSEM Online).

For determination of levels of DNA-DNA relatedness and DNA G +C content, chromosomal DNA was extracted according to the method of Marmur (1961). DNA-DNA reassociation analyses were performed according to the microdilution well technique, by using photobiotin for DNA labelling (Ezaki et al., 1989). Strain YIT 11318 was not included in the DNA-DNA hybridization studies because it showed very high 16S rRNA gene sequence similarity to strain YIT $11306^{\mathrm{T}}$. Reciprocal hybridization experiments were performed for each pair of strains at $40{ }^{\circ} \mathrm{C}$ for $15 \mathrm{~min}$ in the presence of $50 \%$ formamide. Levels of DNA-DNA relatedness between strains YIT $11306^{\mathrm{T}}$ and YIT 11317 were $74-88 \%$, indicating that these two strains belonged to the same taxon, whereas levels of DNA-DNA relatedness between strains YIT $11306^{\mathrm{T}}$ and $L$. agilis YIT $0253^{\mathrm{T}}, L$. mali YIT $0449^{\mathrm{T}}$, L. salivarius subsp. salivarius YIT $0104^{\mathrm{T}}$ and L. satsumensis YIT $11287^{\mathrm{T}}$ were 6, 9,8 and $9 \%$, respectively. These latter values were well below the $70 \%$ cut-off value recommended for the distinction of separate bacterial species (Stackebrandt \& Goebel, 1994). To assess DNA base compositions (G $+\mathrm{C}$ content), DNA was enzymically degraded into nucleosides as described by Mesbah et al. (1989) and then separated by HPLC. The DNA G $+\mathrm{C}$ contents of strains YIT $11306^{\mathrm{T}}$ and YIT 11317 were 37.5 and $36.9 \mathrm{~mol} \%$, respectively.

Morphological, cultural and biochemical testing according to standard techniques was performed at $30{ }^{\circ} \mathrm{C}$ unless otherwise stated. Cell shape, cell size and Gram staining were determined by using cultures grown in MRS broth at $30{ }^{\circ} \mathrm{C}$ for $16 \mathrm{~h}$. Motility was tested in MRS soft agar $(0.15 \%)$, and flagella on cells from 12 -h cultures in MRS broth were observed under a transmission electron microscope (JEM-1200EX; JEOL) by negative staining with $2 \%$ uranium acetate. Transmission electron microscopy revealed the presence of peritrichous flagella (Fig. 3). Catalase activity was determined by using cells grown on MRS agar. Gas production from glucose was determined with a Durham tube in MRS broth. Production of dextran was assessed on MRS agar in which glucose was replaced with $2 \%(\mathrm{w} / \mathrm{v})$ sucrose. Growth at various temperatures 


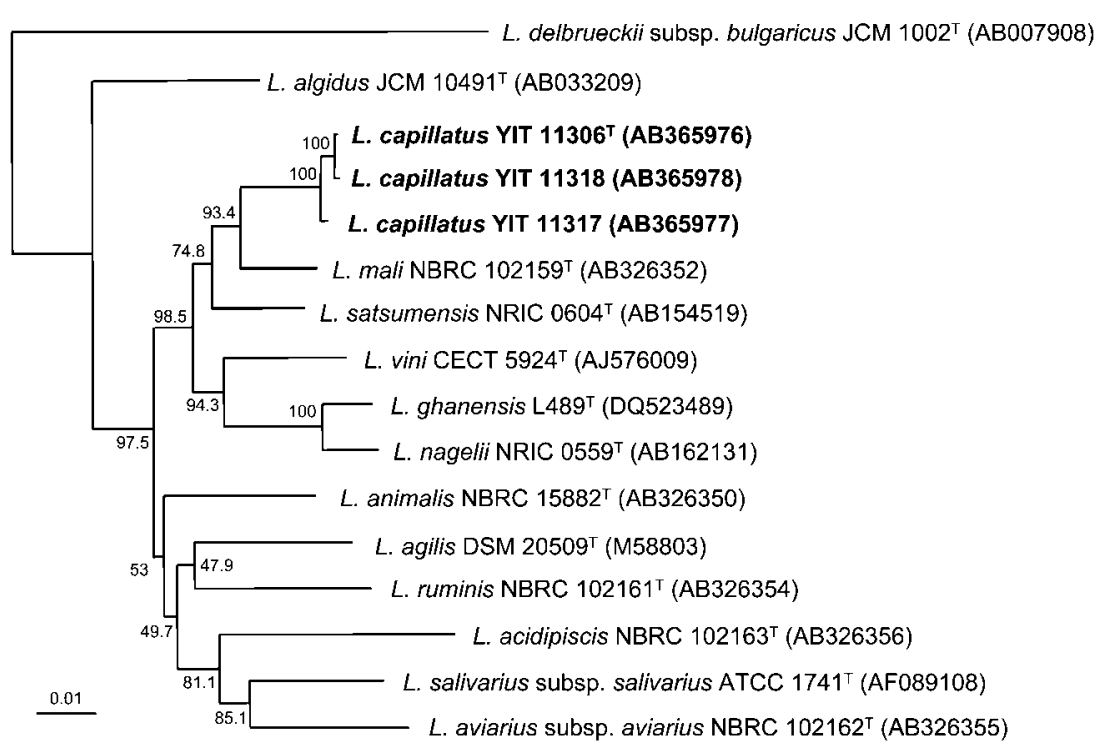

Fig. 2. Phylogenetic tree based on $16 \mathrm{~S}$ rRNA gene sequences showing the relationship of strains YIT $11306^{\top}$, YIT 11317 and YIT 11318 with closely related Lactobacillus species. The tree was constructed by using the neighbourjoining method on the basis of a comparison of approximately $1460 \mathrm{nt}$; Lactobacillus de/brueckii subsp. bulgaricus JCM $1002^{\top}$ was used as an outgroup. Bootstrap values (\%) based on 1000 replications are given at nodes. Bar, $1 \%$ sequence divergence.

and $\mathrm{pH}$, growth in the presence of $\mathrm{NaCl}$, reduction of nitrate and production of ammonia from arginine were determined according to Barrow \& Feltham (1993). Carbohydrate fermentation tests were carried out by using the API 50 CHL system (bioMerieux) according to the manufacturer's instructions. The isomers of lactic acid

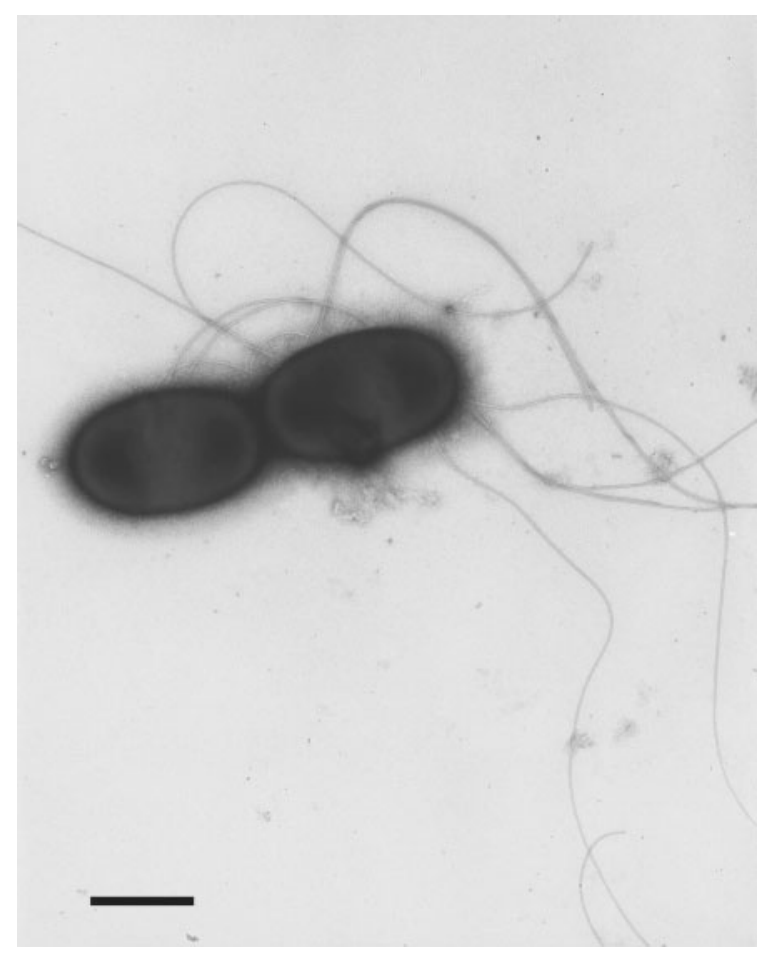

Fig. 3. Transmission electron micrograph of peritrichous flagella of cells of strain YIT $11306^{\top}$ grown in MRS broth at $30{ }^{\circ} \mathrm{C}$ for $12 \mathrm{~h}$. Bar, $1 \mu \mathrm{m}$. formed from glucose were determined with a D/L-lactic acid enzymic kit (R-Biopharm AG).

Various phenotypic characteristics of the novel strains differed from those of L. mali (Carr \& Davies, 1970; Kaneuchi et al., 1988; Nonomura, 1983) and L. satsumensis (Endo \& Okada, 2005), their phylogenetically closest relatives (Table 1). According to the data obtained, the three novel strains are genetically distinguishable from recognized species of lactic acid bacteria and thus represent a novel species, for which we suggest the name Lactobacillus capillatus sp. nov.

\section{Description of Lactobacillus capillatus sp. nov.}

Lactobacillus capillatus (ca.pil.la'tus. L. masc. adj. capillatus hairy, referring to the characteristic of having long, hairy flagella).

Cells are rod-shaped, $0.8-1.2 \times 1.5-2 \mu \mathrm{m}$, and occur singly, in pairs or in short chains comprising three or four cells. Cells are Gram-positive, catalase-negative, motile by means of peritrichous flagella, non-sporeforming and facultatively anaerobic. After anaerobic growth at $30{ }^{\circ} \mathrm{C}$ for $48 \mathrm{~h}$, colonies on MRS agar are 2$3 \mathrm{~mm}$ in diameter; they are white, opaque, smooth and circular with entire edges. In MRS broth, growth occurs at $15{ }^{\circ} \mathrm{C}$ but not at $45{ }^{\circ} \mathrm{C}$. Growth occurs at $\mathrm{pH} 4.0$ and $\mathrm{pH}$ 8.0. No growth occurs at $8 \% \mathrm{NaCl}$. No gas is produced from glucose. Both L-lactic acid $(80 \%)$ and Dlactic acid $(20 \%)$ are produced as the end products from glucose. Ammonia is not produced from arginine. Nitrate is not reduced. Acid is produced from methyl $\beta$-xyloside, galactose, D-glucose, D-fructose, inositol, methyl $\alpha$-Dmannoside, methyl $\alpha$-D-glucoside, $N$-acetylglucosamine, amygdalin, arbutin, salicin, melibiose, sucrose, xylitol and $\beta$-gentiobiose, but not from glycerol, erythritol, Darabinose, ribose, D-xylose, L-xylose, adonitol, D-man- 
Table 1. Differential phenotypic characteristics between strains YIT $11306^{\top}$ and YIT 11317 and genetically closely related lactobacilli

Taxa: 1, strain YIT $11306^{\mathrm{T}}$; 2, strain YIT $11317 ; 3$, L. mali; 4, L. satsumensis. +, Positive; -, negative; $(+)$, weakly positive; $\mathrm{V}$, variable.

\begin{tabular}{|c|c|c|c|c|}
\hline Characteristic & 1 & 2 & 3 & 4 \\
\hline \multicolumn{5}{|l|}{ Acid production from: } \\
\hline Ribose & - & - & $\mathrm{V}^{*}$ & $-\dagger$ \\
\hline Methyl $\beta$-xyloside & + & $(+)$ & $-\ddagger$ & $-\ddagger$ \\
\hline Galactose & + & + & $+^{*}$ & $\mathrm{v} \dagger$ \\
\hline D-Mannose & - & - & $+\ddagger$ & $+末$ \\
\hline L-Sorbose & - & + & $\mathrm{V}^{*}$ & $+\neq$ \\
\hline Rhamnose & - & - & $\mathrm{V}^{*}$ & $+\ddagger$ \\
\hline Inositol & + & + & $-{ }^{*}$ & $-\ddagger$ \\
\hline Mannitol & - & + & $+^{*}$ & $+\dagger$ \\
\hline Sorbitol & - & - & $+\ddagger$ & $+末$ \\
\hline Salicin & + & + & -末 & $+\dagger$ \\
\hline Cellobiose & + & - & $+^{*}$ & $-\dagger$ \\
\hline Maltose & - & - & $\mathrm{v}^{*}$ & $+末$ \\
\hline Lactose & - & - & $\mathrm{V}^{*}$ & $-\dagger$ \\
\hline Melibiose & + & + & $\mathrm{V}^{*}$ & $-\dagger$ \\
\hline Trehalose & - & - & $+^{*}$ & $+\dagger$ \\
\hline Inulin & - & - & $+^{*}$ & $-\ddagger$ \\
\hline Melezitose & - & - & $\mathrm{V}^{*}$ & $\mathrm{v} \dagger$ \\
\hline Raffinose & - & - & $\mathrm{V}^{\star}$ & $-\dagger$ \\
\hline Xylitol & + & + & $-末$ & $-\ddagger$ \\
\hline Turanose & - & - & $-{ }^{\star}$ & $+末$ \\
\hline D-Tagatose & - & - & $+^{*}$ & $+末$ \\
\hline L-Arabitol & - & + & $-末$ & $-\ddagger$ \\
\hline Gluconate & - & - & $-\ddagger$ & $\mathrm{v} \dagger$ \\
\hline Growth at $45{ }^{\circ} \mathrm{C}$ & - & - & $\mathrm{V}^{*}$ & $+\dagger$ \\
\hline Catalase production & - & - & $\mathrm{V}^{*}$ & $-\dagger$ \\
\hline Isomer of lactic acid & $\mathrm{L}$ & $\mathrm{L}$ & $\mathrm{DL} \$$ & $\mathrm{~L} \dagger$ \\
\hline $\begin{array}{l}\text { DNA G + C content } \\
(\mathrm{mol} \%)\end{array}$ & 37.5 & 36.9 & $32-33.7^{\star}$ & $39-41 \dagger$ \\
\hline
\end{tabular}

${ }^{\star}$ Data for reference species are from Kaneuchi et al. (1988). $\dagger$ Data for reference species are from Endo \& Okada (2005). $\ddagger$ Data for reference species are from Rodas et al. (2006). $\S$ Data for reference species are from Carr \& Davies (1970).

nose, rhamnose, dulcitol, sorbitol, maltose, lactose, trehalose, inulin, melezitose, raffinose, starch, glycogen, turanose, D-lyxose, D-tagatose, D-fucose, L-fucose, Darabitol, L-arabitol, gluconate, 2-ketogluconate or 5ketogluconate. Acid production from L-arabinose, Lsorbose, mannitol, cellobiose and L-arabitol is straindependent. Aesculin is hydrolysed. Dextran is produced from sucrose. Cells contain meso-diaminopimelic acid in the peptidoglycan. The DNA G $+\mathrm{C}$ content of the type strain is $37.5 \mathrm{~mol} \%$. Phylogenetic analysis of the $16 \mathrm{~S}$ rRNA gene sequence places the species in the $L$. mali subgroup of lactobacilli.
The type strain, YIT $11306^{\mathrm{T}} \quad\left(=\mathrm{JCM} \quad 15044^{\mathrm{T}}=\mathrm{BCRC}\right.$ $17811^{\mathrm{T}}=\mathrm{DSM} 19910^{\mathrm{T}}$ ), was isolated from fermented brine used for stinky tofu production in Taipei County, Taiwan, in 2005. YIT 11317 and YIT 11318, also isolated from stinky tofu brine, are additional strains of the species.

\section{Acknowledgements}

We would like to thank Minoru Ando (Yakult Central Institute) for technical assistance with observation of flagella and Chin-Sheng Huang (the manager of Chin-Chi Food Co. Ltd, Taiwan) for support during sampling.

\section{References}

Akopyanz, N., Bukanov, N. O., Westblom, T. U., Kresovich, S. \& Berg, D. E. (1992). DNA diversity among clinical isolates of Helicobacter pylori detected by PCR-based RAPD fingerprinting. Nucleic Acids Res 20, 5137-5142.

Barrow, G. I. \& Feltham, R. K. (editors) (1993). Cowan and Steel's Manual for the Identification of Medical Bacteria, 3rd edn. London: Cambridge University Press.

Carr, J. G. \& Davies, P. A. (1970). Homofermentative lactobacilli of ciders including Lactobacillus mali nov. spec. J Appl Bacteriol 33, 768774.

Cavalli-Sforza, L. L. \& Edwards, A. W. F. (1967). Phylogenetic analysis models and estimation procedures. Am J Hum Genet 19, 233-257.

Endo, A. \& Okada, S. (2005). Lactobacillus satsumensis sp. nov., isolated from mashes of shochu, a traditional Japanese distilled spirit made from fermented rice and other starchy materials. Int J Syst Evol Microbiol 55, 83-85.

Ezaki, T., Hashimoto, Y. \& Yabuuchi, E. (1989). Fluorometric deoxyribonucleic acid-deoxyribonucleic acid hybridization in microdilution wells as an alternative to membrane filter hybridization in which radioisotopes are used to determine genetic relatedness among bacterial strains. Int J Syst Bacteriol 39, 224-229.

Felsenstein, J. (1985). Confidence limits on phylogenies: an approach using the bootstrap. Evolution 39, 783-791.

Felsenstein, J. (2007). PHYLIP (phylogeny interface package), version 3.67. Distributed by the author. Department of Genome Sciences, University of Washington, Seattle, USA.

Fitch, W. M. (1971). Toward defining the course of evolution: minimum change for a specific tree topology. Syst Zool 20, 406-416.

Kaneuchi, C., Seki, M. \& Komagata, K. (1988). Taxonomic study of Lactobacillus mali Carr and Davis 1970 and related strains: validation of Lactobacillus mali Carr and Davis 1970 over Lactobacillus yamanashiensis Nonomura 1983. Int J Syst Bacteriol 38, 269-272.

Marmur, J. (1961). A procedure for the isolation of deoxyribonucleic acid from microorganisms. J Mol Biol 3, 208-218.

Mesbah, M., Premachandran, U. \& Whitman, W. B. (1989). Precise measurement of the $\mathrm{G}+\mathrm{C}$ content of deoxyribonucleic acid by highperformance liquid chromatography. Int J Syst Bacteriol 39, 159-167.

Miyake, T., Watanabe, K., Watanabe, T. \& Oyaizu, H. (1998). Phylogenetic analysis of the genus Bifidobacterium and related genera based on 16S rDNA sequences. Microbiol Immunol 42, 661-667.

Nonomura, H. (1983). Lactobacillus yamanashiensis subsp. yamanashiensis and Lactobacillus yamanashiensis subsp. mali sp. and subsp. nov., nom. rev. Int J Syst Bacteriol 33, 406-407. 
Rodas, A. M., Chenoll, E., Macián, M. C., Ferrer, S., Pardo, I. \& Aznar, R. (2006). Lactobacillus vini sp. nov., a wine lactic acid bacterium homofermentative for pentoses. Int J Syst Evol Microbiol 56, 513-517.

Saitou, N. \& Nei, M. (1987). The neighbour-joining method: a new method for reconstructing phylogenetic trees. Mol Biol Evol 4, 406425.

Stackebrandt, E. \& Goebel, B. M. (1994). Taxonomic note: a place for DNA-DNA reassociation and $16 \mathrm{~S}$ rRNA sequence analysis in the present species definition in bacteriology. Int J Syst Bacteriol 44, 846849.

Thompson, J. D., Gibson, T. J., Plewniak, F., Jeanmougin, F. \& Higgins, D. G. (1997). The CLUSTAL_X windows interface: flexible strategies for multiple sequence alignment aided by quality analysis tools. Nucleic Acids Res 25, 4876-4882.

Zhu, H., Qu, F. \& Zhu, L. H. (1993). Isolation of genomic DNAs from plants, fungi, and bacteria using benzyl chloride. Nucleic Acids Res 21, 5279-5280. 